\title{
PEMEROLEHAN BAHASA PADA ANAK USIA 2-3 TAHUN MELALUI METODE BERNYANYI DI PAUD NUR INSANI PIYAMAN, WONOSARI, GUNUNGKIDUL
}

\section{Language Extension in Children Of 2-3 Years Age Through Methods Of Serving In PAUD Nur Insani Piyaman, Wonosari, Gunungkidul}

\author{
Marlina Dwisiwi Widyorini, Julananda Putri Sahasti, dan Sumarlam \\ Magister Pendidikan Bahasa Indonesia \\ Universitas Sebelas Maret Surakarta, Indonesia \\ Pos-el: mdsiwidyorini@student.uns.ac.id,julananda@student.uns.ac.id \\ tanggal naskah masuk 6 November 2018 \\ tanggal akhir penyuntingan 4 Desember 2018
}

\begin{abstract}
Language is the main means of communication in human life in this world either in written form, oral and which is only a certain symbol. Without human language can not communicate because humans are social beings who inevitably have to interact with other humans. Language acquisition in humans begins with children when learning to speak. Language acquisition in each child is not the same, according to his age. In this research will be studied the acquisition of child language on phonology, morphology, and syntax aspects. This research uses qualitative research method with naturalistic technique. Sources of data in this study are the students of class A PAUD Nur Insani, Piyaman, Wonosari, Gunungkidul. The purpose of this study are: 1) explain the acquisition of phonology of children aged 2-3 years in early childhood Nur Insani Piyaman, Wonosari, Gunungkidul; 2) explain the acquisition of morphology of children aged 2-3 years in early childhood Nur Insani Piyaman, Wonosari, Gunungkidul; and 3) describes the acquisition of syntactics of children aged 2-3 years in early childhood Nur Insani Piyaman, Wonosari, Gunungkidul.
\end{abstract}

Keywords: language acquisition of child, phonology, morphology, syntax

Abstrak

Bahasa merupakan sarana komunikasi utama dalam kehidupan manusia di dunia ini baik dalam bentuk tulisan, lisan maupun yang hanya berupa simbol tertentu. Tanpa bahasa manusia tidak dapat berkomunikasi karena manusia adalah makhluk sosial yang mau tidak mau harus berinteraksi dengan manusia lain. Pemerolehan bahasa pada manusia diawali dari anak-anak ketika belajar berbicara. Pemerolehan bahasa pada setiap anak tidak sama, sesuai dengan usianya. Pada penelitian ini akan dikaji pemerolehan bahasa anak pada aspek fonologi, morfologi, dan sintaksisnya. Penelitian ini menggunakan metode penelitian kualitatif dengan teknik naturalistik. Sumber data dalam penelitian ini adalah siswa kelas A PAUD Nur Insani, Piyaman, Wonosari, Gunungkidul. Tujuan penelitian ini yaitu: 1) menjelaskan pemerolehan fonologi anak usia 2-3 tahun di PAUD Nur Insani Piyaman, Wonosari, Gunungkidul; 2) menjelaskan pemerolehan morfologi anak usia 2-3 tahun di PAUD Nur Insani Piyaman, Wonosari, Gunungkidul; dan 3) menjelaskan pemerolehan sintaksis anak usia 2-3 tahun di PAUD Nur Insani Piyaman, Wonosari, Gunungkidul.

Kata-kata kunci: pemerolehan bahasa anak, fonologi, morfologi, sintaksis

\section{PENDAHULUAN}

Bahasa merupakan sarana komunikasi utama dalam kehidupan manusia di dunia ini baik dalam bentuk tulisan, lisan, maupun yang hanya berupa simbol tertentu. Tanpa bahasa manusia tidak bisa berkomunikasi karena manusia adalah makhluk sosial yang harus saling berinteraksi satu sama lain. Dalam interaksi pasti ada komunikasi yang didalam komunikasi itu sendiri terdapat bahasa. Bahasa sebagai alat komunikasi yang diperoleh sejak lahir. Pada awal bayi lahir belum memiliki kemampuan dalam 
berbicara dengan orang lain. Penguasaan sebuah bahasa oleh seorang anak dimulai dengan perolehan bahasa pertama yang sering disebut bahasa ibu. Pemerolehan bahasa merupakan sebuah proses yang sangat panjang sejak anak belum mengenal sebuah bahasa sampai fasih berbahasa. Setelah bahasa ibu diperoleh maka pada usa yetsyenyi anak memperoleh bahasa laon atau bahasa kedua yag ia kenal sebagai pengetahuan baru. Bahasa ibu adalah bahasa pertama yang dikuasai manusia sejak awal hidupnya melalui interaksi dengan keluarga dan lingkungan masyarakat.

Berbagai penelitian menunjukkan bahwa anak-anak merasakan bahasa ibu melalui beberapa hal, di antaranya adalah dengan pertanuaan yang sering diajukan, respon verba nonvernal dan berinteraksi. Bahasa menjadi objek kajian linguistik harus dibedakan dari berbahasa, yakni kegiatan mannusia dalam memproduksi dan meresepsi bahasa. Proses bahasa dimuai dari enkode semantik. Gramatik dan fonologi. Semantik dan gramatik berlangsung dalam otak, sedangkan fonologi dimulai dari otak lalu dilanjutkan pelaksanaannya oleh alat-alat berbicara yang melibatkan sistem saraf otak.

Berdasarkan hal tersebut, yang termasuk tingkat pencapaian perkembangan anak pada usia 2-3 tahun pada aspek berbicara diantaranya mengulang kalimat sederhana, menjawab pertanyaan sederhana, menceritakan kembali cerita/ dongeng yang pernah didengar. Mengulang kalimat sederhana ditunjukkan anak mengulang lirik lagu. Menjawab pertanyaan sederhana ditunjukkan anak paham lirik lagu yang dinyanyikan ketika menjawab pertanyaan tentang isi lagu. Metode pengajaran PAUD yang dikemukakan oleh Maitoh, dkk. Satu diantaranya adalah bernyanyi. Honig dalam Solehuddin (1998:11) menjelaskan bahwa bernyanyi merupakan bakat yang bersifat alamiah, yang dimiliki serta dibutuhkan oleh setiap individu. Masitoh, dkk (2007:11-12) menyatakan bahwa pengalaman dalam bernyanyi dapat membantu mengembangkan kemampuan daya pikir dan bahasa anak serta dapat dijadikan sebagai pusat lingkungan belajar anak secara lebih menyeluruh.

Belajar bahasa akan lebih mudah apabila mereka memiliki lingkungan yang baik, oleh karena itu dibutuhkan kondisi dan stimulus yang sesuai dengan kebutuhan anak agar pertumbuhan dan perkembangan berbahasa anak tercapai secara optimal. Salah satunya dengan menggunaan metode bernyanyi yang merupakan cara penyampaian atau penyajian metri secara lisan dari guru kepada anak untuk menjelaskan hal-hal baru yang dapat mengembangkan berbagai kompetensi dasar anak. Bernyanyi memiliki peran pennting bukan saja dalam membutuhkan minat dan keberanian, tapi juga dalam mengembangkan bahasa dan kosa kata anak.

Metode bernyanyi dapat disajikan pada anak usia 2-3 tahun dalam bentuk yang menarik yaitu dapat dilakukan melalui pemutaran lagu dari kaset atau praktik langsung. Dengan kata lain, bernyanyi mempunyai makna penting bagi perkembangan bahasa anak dalam berkomunikasi secara efektif dan efisien sehingga proses percakapan menjadi komunikatif, pendengaran anak dapat difungsikan dengan baik untuk membantu pemerolehan bahasa, menambah perbendaharaan kosa kata, dan menambah kemampuan mengucapkan kata-kata, serta melatih merangkai kalimat sesuai dengan tahap perkembangannya.

Langkah-langkah dalam proses pemerolehan bahasa terhadap anak usia 23 tahun adalah suatu hal yang menarik untuk dikaji. Untuk itu para ahli linguistik banyak yang meneliti terkait pemerolehan bahasa anak. Saat ini pemerolehan bahasa adalah salah satu kajian untuk mengetahui bagaimana perkembangan bahasa anak mulai dari umur 2-3 tahun. Berdasarkan teori Ingram bahwa fonologi menunjukkan pola yang jauh lebih bervariasi dengan adanya sistem yang biasa terlihat dalam 
pemerolehan fonology anak, dan beberapa anak mengembangkan pemerolehan fonologinya cukup berbeda dari target morfologi dan dari biasanya dalam berkembang fonologi. Kesulitan ujaran tidak dibatasi pada satu bagian ujaran, tetapi terjadi dalam berbagai bidang fonologi. Di samping itu, Chomsky (1975) mengemukakan bahwa:

"has determined that being biologically prepared to acquire language regardless of setting is due to the child's language acquisition device (LAD), which is used as a mechanism for working out the rules of language. Chomsky believed that all human languages share common principles, such as all languages have verbs and nouns, and it was the child's task to establish how the specific. LAD already contains the concept of verb tense and so by listening to word forms such as "worked" or "played". The child will then form a hypothesis that the past tense of verbs are formed by adding the sound $/ d /, / t /$ or /id/ to the base form."

Chomsky percaya bahwa semua bahasa manusia secara umum memiliki kata kerja dan kata benda yang digunakan untuk mengungkapkan prinsip-prinsip yang mendasari, misalnya Language Acquisition Device (LAD) yang berisi konsep-konsep kata kerja dengan mendengarkan bentuk kata seperti bekerja atau dimainkan anak itu kemudian akan membentuk hipotesis bahwa bentuk lampau dari kata kerja dibentuk dengan menambahkan suara /d/, /t/ atau /id/ ke bentuk dasar.

Menurut Kuhl (2008); untuk memperoleh bahasa, anak-anak harus menemukan perbedaan fonetik yang akan digunakan dalam budaya bahasa mereka dan melakukannya dengan diskriminasi antara hampir semua unit fonetik bahasa di ketahui. Selama tahun pertama kehidupan anak, anak mulai memahami ujaran dengan membentuk peta persepsi dari ujaran mereka dari apa yang didengar di lingkungan mereka. Penelitian Kuhl difokuskan pada mekanisme yang mendasari transisi perkembangan fonologi anak dari kapasitas fonetik universal yang merupakan diskriminasi fonetik asli. Di dalam pemerolehan bahasa terkait dengan pemerolehan sintaksis, semantik, dan pemerolehan fonology. Bagian-bagian bahasa tersebut diperoleh dan berkembang secara bersamaan, walaupun didalam pembahasannya bagian-bagian bahasa itu dapat dikerjakan secara terpisah. Di dalam penelitian ini dikaji tentang perkembangan pemerolehan bahasa khususnya perkembangan fonologi anak berusia dua tahun dua bulan yang bernama Aisyah. Banyak hal yang dapat diidentifikasi dalam pemerolehan bahasa yakni pemerolehan bahasa dengan melihat perkembangan gramatika, fonologis, semantik, sintaksis, serta perkembangan pragmatik.

Berdasarkan hasil observasi yang dilakukan di Kelompok Bermain (KB) PAUD Nur Insani Piyaman, Wonosari, Gunungkidul, perkembangan kemampuan dasar berbahasa anak dapat dikatakan masih belum memenhi harapan. Masih banyak anak yang memperoleh hasil belajar dengan belum berkembang dan mulai berkembang, sedangkan hasil belajar yang diharapkan adalah berkembang sesuai harapan. Di Kelompok Bermain (KB) PAUD Nur Insani Piyaman, Wonosari, Gunungkidul, memiliki 8 yang terdiri dari 5 laki-laki dan 3 perempuan. Dari 8 siswa, masih terdapat 6 siswa yang masih terkendala pada perkembangan pemero-lehan bahasa nya. Anak masih sulit untuk mengekspresikan, mengomunikasikan pikiran dan mengutarakan perasaan dengan komunikasi melalui ujaran yang tepat dan jelas ketika mengulang kalimat sederhana dan menjawab pertanyaan tentang lirik lagu. Hal tersebut mendasari munculnya gagasan untuk menganalisis pemerolehan bahasa melalui metode bernyanyi yang berfokus pada aktivitas anak dalam membangun pengembangan pemerolehan bahasa. 
Berdasarkan latar belakang di atas, maka peneliti tertarik untuk mengambil judul penelitian "Pemerolehan Bahasa pada Anak Usia 2-3 Tahun melalui Metode Bernyanyi di PAUD Nur Insani Piyaman, Wonosari, Gunungkidul". Tujuan penelitian ini yaitu: 1) menjelaskan pemerolehan fonologi anak usia 2-3 tahun di PAUD Nur Insani Piyaman, Wonosari, Gunungkidul; 2) menjelaskan pemerolehan morfologi anak usia 2-3 tahun di PAUD Nur Insani Piyaman, Wonosari, Gunungkidul; dan 3) menjelaskan pemerolehan sintaksis anak usia 2-3 tahun di PAUD Nur Insani Piyaman, Wonosari, Gunungkidul.

\section{LANDASAN TEORI}

\section{Pemerolehan Fonologi}

Dalam ilmu linguistik fonologi sebagai salah satu aspek yang terdapat didalamnya yang mempelajari tentang fonem serta bunyi-bunyi yang diucapkan anak sejak umur satu tahun yang akan dilihat sebagai bagian dari pemerolehan bahasa. Lyons (1995:110) mengemukakan definisi umum tentang fonem yang dikemukakan bahwa ada dua bunyi yang secara fonetis berbeda dalam lingkungan yang sama yang sangat berpengaruh untuk membedakan kata-kata yang berlainan. Misalnya [1] dan [r] adalah masuk dalam fonem-fonem yang jauh berbeda dalam bahasa Inggris karena membedakan pasangan kata-kata. Misalnya: kata right dan light, lot dan rot. Didalam bahasa Indonesia beberapa hal yang dapat dilihat dalam kata-kata seperti: bambu dan rambu, tombak dan rombak, buku dan kuku dan sebagainya.

Perkembangan sistem fonologi anakanak dimulai jika anak-anak dapat mengucapkan kata pertama dalam bahasa yang benar yaitu untuk menyampaikan arti. Dengan demikian pemerolehan sistem bunyi yang sebenarnya dimulai pada saat anak-anak mengucapkan kata pertama untuk tujuan komunikasi ketika anak-anak berusia kurang lebih 1 tahun. Menurut Ingram (1987:420) dalam pemerolehan fonologi setiap individu mempunyai variasi, yaitu: 1) variasi performance yang timbul berdasarkan keturunan dalam bentuk pilihan yang berbeda atau kemampuan perbedaan tipe belajar sehingga menentukan perbedaan diantara anak, 2) variasi lingkungan yang disebabkan oleh perbedaan dalam input pada anak yang berbeda, 3) variasi linguistik yang timbul dari sejumlah pilihan yang berbeda pada piranti pemerolehan bahasa yang menyediakan pemerolehan terutama jenis struktur. Dengan demikian jenis variasi individu dalam pemerolehan fonologi dipengaruhi berdasarkan ketiga variasi tersebut.

\section{Pemerolehan Morfologi}

Kata morfologi berasal dari kata morf yang berarti bentuk dan kata logi yang berarti ilmu. Secara harfiah, morfologi berarti ilmu mengenai bentuk. Dalam kajian linguistik, morfologi berarti ilmu mengenai bentuk-bentuk dan pembentukan kata.

Kridalaksana (2001:51) berpendapat bahwa morfologi adalah bidang linguistik yang mempelajari morfem dan kombinasikombinasinya; bagian dari struktur bahasa yang mencakup kata dan bagian-bagian kata yakni morfem. Sedangkan Ramlan (1997:21) berpendapat bahwa morfologi adalah ilmu bahasa yang mempelajari seluk beluk kata serta fungsi perubahanperubahan bentuk kata itu, baik fungsi gramatikal maupun fungsi semantik.

Jadi, dapat disintesiskan bahwa morfologi adalah ilmu bahasa yang mempelajari morfem, seluk beluk kata, serta fungi perubahan-perubahan bentuk kata tersebut, baik fungsi gramatikal maupun fungsi semantiknya.

Indah dan Abdurrahman (2008:111)

menyatakan bahwa pada proses pemerolehan morfologi, anak melakukan deferensiasi kelas kata yang meliputi pembentukan kata jamak, pembentukan imbuhan, dan perubahan kata kerja. Selain itu, anak akan memahami hukum pemerolehan yang meliputi pemahaman 
bentuk dan macam makna kata berdasarkan konteks, membedakan katakata tugas dan imbuhannya, membuat generalisasi, memperhatikan akhiran dan awalan, serta memahami aturan penempatan kata.

\section{Pemerolehan Sintaksis}

Pemerolehan sintaksis dimulai ketika anak-anak mampu menggabungkan kata (dua kata atau lebih). Kemampuan ini biasanya pada anak berusia dua tahun atau lebih. Oleh karena itu, tahap holofrasis berhubungan dengan perkembangan pemerolehan sintaksis. Ada beberapa teori pemerolehan sintaksis yang berkembang, yaitu: (1) teori tata bahasa Pivot; (2) teori hubungan tata bahasa nurani; (3) teori hubungan tata bahasa dan informasi situasi; dan (4) teori kumulatif kompleks.

Pemerolehan sintaksis menurut Teori Pivot (Indah dan Abdurrahman, 2008: 111), ditandai dengan kecenderungan anak menggunakan kata-kata fungsi yang bercirikan: (1) terdapat pada awal atau akhir kalimat; (2) jumlahnya terbatas; (3) jarang memunculkan kata baru; (4) tidak muncul sendirian, (5) tidak muncul bersamaan dalam satu kalimat; dan (6) selalu merujuk pada kata-kata lain.

Pemerolehan sintaksis menurut teori tata bahasa nurani (generatif transformasi) dari Chomsky (1957-1965) sangat berasa pengaruhnya dalam pengkajian perkembangan sintaksis kanak-kanak. Menurut Chomsky, hubungan-hubungan tata bahasa tertentu seperti "subject-of, predicate-of, dan direct object-of" adalah bersifat universal dan dimiliki semua bahasa yang ada di dunia ini. Berdasarkan teori Chomsky tersebut, Neil (1970) menyatakan pengetahuan kanak-kanak mengenai hubungan-hubungan tatabahasa universal ini bersifat "nurani". Maka, itu akan langsung mempengaruhi pemerolehan sintaksis kanak-kanak sejak tahap awalnya. Jadi, pemerolehan sintaksis ditentukan oleh hubunganhubungan tata bahasa universal ini.
Teori hubungan tata bahasa dan informasi situasi dikembangkan oleh Bloom (1970). Bloom berpendapat bahwa hubungan-hubungan tata bahasa tanpa merujuk pada informasi situasi (konteks) belum mencukupi untuk menganalisis ucapan atau bahasa kanak-kanak. Misalnya, "mama, kue" dapat berarti meminta kue, menunjuk kue, menawarkan kue, memberi tahu jika kuenya jatuh dan lain sebagainya.

Selain ketiga teori di atas, ada satu lagi teori pemerolehan sintaksis yang berkembang yaitu teori kumulatif kompleks. Teori ini dikemukakan oleh Brown (1973) berdasarkan data yang dikumpulkannya. Menurut Brown, urutan pemerolehan sintaksis oleh kanak-kanak ditentukan oleh kumulatif kompleks semantik morfem dan kumulatif kompleks tata bahasa yang sedang diperoleh. Jadi, sama sekali tidak ditentukan oleh frekuensi munculnya morfem atau kata-kata itu dalam ucapan orang dewasa. Dari tiap orang kanak-kanak (berusia dua tahun) yang sedang memperoleh bahasa Inggris yang diteliti Brown ternyata morfem yang pertama kali dikuasai adalah progressive-ing dari kata kerja, padahal bentuk ini tidak sering muncul dalam ucapan-ucapan orang dewasa.

Setelah progressive-ing baru muncul kata depan in, kemudian on, dan diikuti oleh bentuk jamak, dengan $s$. Sedangkan artikel the dan $a$ yang lebih sering muncul dalam ucapanucapan orang dewasa baru muncul pada tahap ke 8. Urutan perkembangan sintaksis yang dilaporkan oleh Brown hampir sama dengan urutan perkembangan hubungan-hubungan sintaksis yang dilaporkan oleh sejumlah pakar lain.

\section{METODE PENELITIAN}

Penelitian ini menggunakan metode penelitian kualitatif dengan teknik naturalistik karena memfokuskan perhatian pada situasi kehidupan nyata yang dilakukan fokus kepada kondisi objek 
yang alamiah, tentang situasi sosial di kelas, yakni permasalahan mengenai pemerolehan fonologi, morfologi, dan sintaksis pada anak usia 2-3 tahun melalui metode bernyanyi di PAUD Nur Insani Piyaman, Wonosari, Gunungkidul.

Sugiyono (2013:15) menjelaskan bahwa metode penelitian kualitatif adalah metode penelitian yang berlandaskan pada filsafat positivisme, digunakan untuk meneliti pada kondisi objek yang alamiah, (sebagai lawannya adalah eksperimen) dimana peneliti sebagai instrumen kunci. Lokasi dalam penelitian ini dilakukan di Kelompok Bermain (KB) PAUD Nur Insani, Piyaman, Wonosari, Gunungkidul. Pengumpulan data, dilakukan dengan metode bernyanyi guna untuk memperoleh pemerolehan fonologi, morfologi, dan sintaksis.

Peneliti melakukan waancara mendalam sehingga dapat berinteraksi dengan sumber data. Penetitian ini juga dilakukan untuk mendapatkan data yang mendalam yakni, suatu data yang mengandung makna. Sumber data dalam penelitian ini adalah siswa kelas A PAUD Nur Insani, Piyaman, Wonosari, Gunungkidul.

\section{PEMBAHASAN}

Metode pembelajaran bahasa melalui lagu pada siswa PAUD Nur Insani juga dapat meningkatkan fonem yang akan diproduksi oleh siswa. Dalam menyanyikan lagu Ayo baris teman-teman, siswa belajar bernyanyi sambil senam di pagi hari tanda mulainya pembelajaran.

Langkah-langkah yang dilakukan Guru dalam Penerapan Metode Bernyanyi pada Anak Usia 2-3 Tahun di Kelompok Bermain PAUD Nur Insani, Piyaman, Wonosari, Gunungkidul.

Berdasarkan hasil wawancara dan observasi yang dilakukan, langkah penerapan metode bernyanyi pada siswa usia 2-3 yahun maka diperoleh data bahwa dalam menerapkan metode bernyanyi guna mengembangkan pemerolehanbahasa anak usia 2-3 tahun di Kelompok Bermain
PAUD Nur Insani, Piyaman, Wonosari, Gunungkidul dilakukan melalui dua langkah yakni langkah pertama dan kedua. Langkah pertama diawali dengan berbaris dihalaman sekolah dengan berbaris sambil bernyanyi dan disertakan gerakan senam yang dipandu oleh guru, lalu guru melakukan tanya jawab seputar lirik lagu Ayo Baris teman-teman. Langkah kedua, dilanjutkan dengan membentuk sebuah lingkaran dan guru memandu siswa untuk menyanyikan bersama, melakukan tanya jawab seputar lirik lagi Ayo Baris temanteman dan diakhiri dengan mengulang nyanyian dengan gerakan secara berkelompok di dalam lingkaran tersebut. Berdasarkan hasil penelitian, sebanyak $70 \%$ guru menggunakan langkah pertama, sedangkan 30\% langkah kedua digunakan hanya untuk melatih pemerolehan bahasa melalui lirik lagu Ayo Baris Teman-teman. Artinya, dalam menerapkan lagu Ayo baris teman-teman guru sangat mempersiapkan siswa agar mereka dapat menunjukkan kemampuan psikomotornya dengan maksimal.

\section{Kemampuan Anak dalam Mengulang Kembali Lirik Lagu}

Berdasarkan hasil wawancara yang dilakukan, menurut guru kelas yakni Ibu Maryam, S.Pd. menjelaskan bahwa kemampuan anak anak dalam mengulang kembali lirik lagu Ayo Baris teman-teman yang ia dengar, sebagaian anak dapat dikatakan sudah cukup baik. Namun perlu dikembangkan lagi untuk mencapai tujuan pembelajaran. Kemampuan anak menghafal dan mengulang kembali lirik lagu, termasuk dalam teori pemerolehan bahasa anak, yaitu pemerolehan fonologi, morfologi, dan sintaksis.

\section{Pemerolehan Fonologi}

Fonologi sebagai salah satu aspek dalam linguistik mempelajari tetang fonem. Bunyi-bunyi yang dinyanyikan oleh siswa PAUD Nur Insani akan dilihat sebagai pemerolehan bahasa. Definisi yang umum tentang fonem dikemukakan oleh 
Lynons adalah dua bunyi yang secara fonetis berbeda dalam lingkungan yang sama, yang berpengaruh untuk membedakan kata-kata lainnya. Misalnya, buku dan kuku.

Pada umur 2-3 tahun, umumnya anak-anak sudah memperoleh dan memproduksi banyak fonem yang dapat membedakan arti kata-kata yang diucapkan. Salah satunya pemerolehan bahasa anak melalui metode bernyanyi Ayo Baris Teman-teman. Lirik lagu Ayo Baris Teman-teman terdiri atas 15 kata yang dapat membantu siswa dalam memperoleh bahasa melalui metode bernyanyi. Berikut lirik lagu Ayo baris teman-teman, yang digunakan guru untuk menambah fonem siswa PAUD Nur Insani.

Ayo baris teman-teman, ayo baris.

Ayo baris teman-teman, ayo baris.

Ayo baris teman-teman, ayo baris.

Ayo baris teman-teman, ayo baris.

Atur barisan

Rentangkan tangan,

Marilah kita senang gembira

Gerakan badan ikut irama......"

Senam gembira kita bersama

Ayo baris teman-teman, ayo baris.

Ayo baris teman-teman, ayo baris.

Ayo baris teman-teman, ayo baris.

Ayo baris teman-teman, ayo baris.

Anak berusia 2-3 tahun biasanya mempunyai kata-kata yang sering diucapkan yang biasanya menghilangkan fonem awal. Misalnya pengucapan kata mandi yang sering menghilangkan fonem $/ \mathrm{m} /$. Berdasarkan hasil observasi, dalam menghafal atau mengulang lirik lagu Ayo Baris teman-teman, siswa masih cenderung menghilangkan dan mengganti fonem yang ada.

Tabel 1

Bunyi Vokal Anak Usia 2-3 Tahun di PAUD Nur Insani

\begin{tabular}{|l|l|l|}
\hline Vokal & /ayo/ & {$[$ ayo] } \\
\hline & /atul/ & {$[$ atur] } \\
\hline & /ntangkan/ & {$[$ rentangkan] } \\
\hline & /enyam/ & {$[$ senam] } \\
\hline
\end{tabular}

\begin{tabular}{|l|l|l|}
\hline Konsonan & /balis/ & {$[$ baris $]$} \\
\hline & /itut/ & {$[$ ikut $]$} \\
\hline & /gembila/ & {$[$ gembira $]$} \\
\hline & /kita/ & {$[$ kita] } \\
\hline & /angan/ & {$[$ tangan] } \\
\hline & /malilah/ & {$[$ marilah] } \\
\hline Reduplikasi & $\begin{array}{l}\text { /eman- } \\
\text { eman/ }\end{array}$ & $\begin{array}{l}{[\text { teman- }} \\
\text { teman] }\end{array}$ \\
\hline
\end{tabular}

Pada tabel di atas, pada usia 2-3 tahun, siswaa hampir menguasai semua fonem vokal dalam Lirik lagu Ayo baris teman-teman, meskipun belum sempurna. Di samping bunyi vokal yang dikuasai, anak-anak PAUD sebagaian juga menghasilkan berbagai konsonan seperti pada tabel dibawah ini.

Tabel 2

Bunyi Konsonan Anak Usia 2-3 Tahun di PAUD Nur Insani

\begin{tabular}{|l|l|l|l|l|l|}
\hline $\begin{array}{l}\text { Titik Cara } \\
\text { Artikulasi }\end{array}$ & Bilabial & Alvolar & $\begin{array}{l}\text { Alveolar } \\
\text { Palatal }\end{array}$ & Velar & Glotal \\
\hline Hambat & & & & $\mathrm{k}$ & \\
\hline Frikatif & & & $\mathrm{s}$ & & \\
\hline Nasal & $\mathrm{m}$ & $\mathrm{n}$ & & & \\
\hline Getar & & & & & \\
\hline Lateral & & 1 & & & \\
\hline Semivokal & & & & & \\
\hline
\end{tabular}

Berdasarkan data yang diperoleh dari subjek peneliti, bunyi vokal sudah muncul pada bunyi konsonan, namun belum semuanya dan kadang-kadang ada bunyi konsonan di awal kalimat dihilangkan. Ada pula bunyi konsonan yang diganti dengan bunyi konsonan lainnya. Data di atas menunjukkan perkembangan bahwa pada anak berusia 2-3 tahun, sudah banyak mengetahui dan memproduksi bermacammacam fonem yang bisa membedakan berbagai macam arti kata-kata yang diucapkan.

Kesanggupan pemerolehan fonologi anak PAUD usia 2-3 tahun pada lirik lagu Ayo baris teman-teman, vokal /y/ pada kata ayo. Kata tersebut diucapkan ketika anak-anak mulai menikmati lagu Ayo baris teman-tema, baik di sekolah maupun saat berlatih di rumah dan mengucap secara spontan ketika guru atau orang tua memancing dengan lagu tersebut. 
Konsonan hambat velar [k] sudah muncul ketika mengucap kata [kita]. Kalimat tersebut muncul ketika guru meberikan lirik lagu ...Kita gembira.

Bunyi nasal [m] sudah terdengar seperti kata [mailah] marilah, [eman] teman. Bunyi getar [r] belum muncul dan sering diganti dengan lateral [1] seperti kata [atu;] atur, [balis] baris, [gembila] gembira, [malilah] marilah. Bunyi nasal [n] suadah mulai terdegar walaupun masih sedikit seperti kata [ntangkan] rentangkan Reduplikasi sudah mulai terdengar seperti kata [eman-man] [teman-teman].

Pemerolehan fonologi pada lirik lagu Ayo baris teman-teman, khususnya bunyi nasal bilabial [m] muncul pada awal kata, dan diyakini bunyi nasal ini sudah dimunculkan pada awal, tengah dan akhir kata. bunyi getar [r] belum terdengar dan cendeng sering diganti dengan lateral [1] seperti kata [atu;] atur, [balis] baris, [gembila] gembira, [malilah] marilah, yang dimunculkan pada bagiam awal, tengah dan akhir kata. Bunyi nasal alveolar [n] sudah mulai terdengar pada kata apabila berada di awal kata. Hal ini terjadi karena pemerolehan leksikon yang mengandung kesua bunyi konsonan tersebut masih dangay terbatas untuk anak berusia 2-3 tahun karena pemerolehan fonologi sangat berkaitan dengan pemerolehan leksikon.

\section{Pemerolehan Morfologi}

Pemerolehan bahasa siswa PAUD Nur Insani melalui lirik lagu Ayo Baris Teman-teman, terdapat kata yang sering diucapkan, yaitu /ayo/: ayo, /balis/: baris, /eman/: teman, /enang/: senang, /gembila/: gembira.

Kata-kata yang diucapkan seperti tersebut diatas hanya satu kaya yang morfofonemik dan belum nampak sekali morfem yang dapat membedakan arti katakata tersebut. kata-kata tersebut lazim hanya berdiri sendiri dan dalam morfologi kata-kata seperti itu dinamakan morfem bebas. Di samping morfem bebas yang muncul dalam pengucapan anak PAUD Nur Insani, dan ada juga morfem terikat yang sebenarnya masih sulit dibedakan dalam setiap ucapannya tanpa memperhatikan konteks dan situasi ketika kata itu diucapkan. Meskipun morfem terikat jarang terdengar, namun tidak berarti bahwa semua kata-kata yang diucapkannya tidak dapat membedakan arti. Ada beberapa kata yang diucapkan mereka yag sebenarnya sudah termasuk dalam morfem terikat, misal saja: enam bersama $\rightarrow$ senam bersama, angan $\rightarrow$ tangan.

Pada contoh di atas, dapat dikategorikan morfem terikat. Ketika mereka menginjak usia 2 tahun atau lebih, kata-kata yang diucapkannya lebih banyak kata-kata yang hampir bisa dikatakan dalam konteks makna kalimat, mereka sudah bisa mengucapkan kata-kata lebih dari satu suku kata. misalnya:

/enam belsama eman-man/ (senam bersama teman-teman)

/ayo balis eman-man di cana/ (ayo baris teman-teman di sana)

/maililah ita enang gembila/ (marilah kita senang gembira)

Ungkapan kata-kata tersebut sering juga diselingi berbagai monomorfemik tersebut, mereka juga sudah mampi mengucapkan prefik /di/. Misalnya:

/Balis cama dinda di cini/ (baris sama adinda di sini)

/Di cana bu dulu uduk/ (di sana bu guru duduk)

Kata-kata yang diucapkan bersamaan dengan prefiks masing sering dibalik atau tidak diurutkan. Dengan memperhatikan klausa atau rangkaian kata-kata yang diucapkannya, ini menunjukkan bahwa merka sudah mampu menyusun kalimat secara teratur menurut tingkat makna sesuai dengan konteks di mana dan ka0pan ungkapan itu diucapkan. Pada usia 2-3 tahun, mereka nampaknya sudah mampu mengucapkan sufiks pada kata-kata tertentu. Misalnya: tangannya)

/Rentangin angannya./ (rentangin dulu) 
Pada kata /rentangin/, sebenarnya anak PUD Nur Insani sudah mampu mengungkapkan sufiks walaupun hanya kata in. Bagi orang dewasa, kata itu bisa diartikan dengan kata rentangkan. Di samping itu, pengaruh sufis in tersebut menunjukkan bahwa anak-anak seusia mereka memang sering terpengaruh dengan lingkungannya. Selain sufiks in ada juga kan pada kalimat /ita kan enam duyu/, yang menandakan bahwa anak-anak berusia 2-3 tahun sudah mampu mengungkapkan kata-kata seru, walaupun ungkapan tersebut hanya secara spontan saja.

\section{Pemerolehan Sintaksis}

Analisis pemerolehan bahasa pada anak PAUD Nur Insani mencakup bagaimana perkembangan bahasa menurut apa yang di produksi dalam lirik lagu Ayo baris teman-teman yang dikembangkan menjadi sebuah kalimat. Kalimat yang dihasilkan masih sangat sederhana dan memerlukan satu oemahaman yang kadang-kadang sulit untuk dimengerti.

Kalimat-kalimat yang diproduksinya masih banyak yang tidak lengkap dan kadang-kadang terpotong dan ditambahi lagi dengan ucapan fonemnya yang belum sempurna. Namun, dari hasil pemerolehan bahasanya masih dapat dimengerti. Dalam pembahasan tentang kalimat-kalimat yang dihasilkan oleh anak PAUD Nur Insani akan terlihat mulai dari ujaran dua kata, tiga kata dan juga multi kata.

1. Kalimat Deklaratif

Memasuki umur 2-3 tahun, anak PAUD Nur Insani sudah banyak menngungkapkan kalimat-kalimat sederhana yang dapat mengandung makna lengkap. Untuk mengetahui bagaimana bentuk kalimat deklaratif yang diungkapkan oleh salah satu anak di PAUD Nur Insan, bentuk percakapan berikut ini dapat memberikan gambaran kalimatkalimat tersebut.

Raya: bu dulu, aya balis dicini. (Raya igin berbaris disebelah sini)
Guru: iya boleh. Rentangkan tangannya ya

Dari kalimat yang diucapkan di atas, nampak kalimat-kalimat yang diucapkan masih terpotong-potong dan ucapannya pun masih belum sempurna. Namun, secara gramatikal, kalimat tersebut sudah dapat digolongkan dalam bentuk kalimat lengkap. Hal ini ditandai dengan Subjek (S)+Verb (V). Secara umum, $\mathrm{S}+\mathrm{V}$ untuk pemerolehan bahasa sudah digolongkan dalam kalimat lengkap karena maknanya hampir sempurna namun ucapan fonem yang keluar masih belum sempurna.

2. Kalimat Imperaktif

Berdasarkan kalimat yang diungkapkan sebelumnya pada bagian morfologi di atas, nampak beberapa kalimat imperatif seperti: / Bu dulu, ayo balis. eman-man ayo balis/ [bu guru, ayo baris, teman-teman ayo baris], /ntangkan tangan/ [rentangkan tangan], /gelakan badanmu/ [gerakan badanmu], /ayo ita puk angan/ [ayo kita tepuk tangan], maka kalimat imperatif yang secara umum diungkapkan oleh anak PAUD Nur Insani sudah mempunyai makna lengkap. Seperti ungkapan sebelumnya, ucapan fonem masih belum sempurna, sedangkan logika kalimat imperatifnya kadang-kadang belum berurutan sesuai dengan kaidah kalimat imperatif. Walaupun demikian, dari susunan kalimatnya, sudah dapat dikatakan bahwa percakapan atau dalam situasi tertentu, kalimat seperti itu lazim apalagi dalam ragam tidak formal khususnya dalam pemerolehan bahasa anak.

3. Kalimat Interogatif

Kalimat interogatif kadangkadang muncul secara sporadik. Pernah pada suatu hari anak PAUD Nur Insani sedang belajar menggambar setelah belajar bernyanyi Ayo Baris teman-teman. Pada pembelajaran mewarnai gambar 
tersebut terdapat suatu gambar anakanak yang sedang bernyanyi sambil menari, secara spontan salah seorang anak langsung bernyanyi Ayo baris teman-teman. Kalimat tersebut biasanya diucapkan ketika ia sedang persiapan senam dipagi hari, setelah bunyi bel masuk terdengar. Dari situasi pengungkapan di atas, nampak bahwa pemerolehan dan produksi kalimat sudah nampak dapat diucapkan tanpa berpikir. Hal ini menunjukkan bahwa kalimat semacam itu sudah diperolehnya dan dengan mudah diproduksinya.

Contoh lain kalimat seperti ini juga sering diungkapkan ketika dia menginginkan sesuatu, misalnya pada saat bel bunyi terdengar namun pada pelajaran hari tersebut tidak ada pembelajaran bernyanyi. Dan secara spontan, setelah anak mendengar bel masuk berbunyi sesekali mereka menyanyakan /bu, ndak balis? [Bu, kita tidak berbaris?]. Dari kalimat-kalimat yang diungkapkan mereka, dapat disimpilkan bahwa anak usia 2-3 tahun sudah dapat mengungkapkan kalimat tanya dengan lengkap sesuai dengan tingkap perkembangannya.

\section{PENUTUP}

Setelah menganalisis hasil data diperoleh bahwa pemerolehan bahasa dalam pemerolehan fonologi pada anak usia 2-3 tahun di PAUD Nur Insani, Piyaman, Wonosari, Gunungkidul, berkaitan erat dengan pemerolehan leksikon. Data yang diper oleh dan bunyi yang diucapkan karena meniru ucapan guru dan ada juga dari orang tua yang memberi latihan dan disertai dengan gerakannya.

Ditinjau dari segi fonologi fonemfonem dalam lirik lagi Ayo baris temanteman, yang dikuasai dengan pemerolehan fonologi yang diperoleh dari awal sangat berhubungan erat dengan perkembangan neurofisiologi abak, proses tahap-tahap perkembangan, maupun unsur-unsur bahasa yang sedikir dei sedikir dikuasai oleh anak sehingga dapat dikatakan bahwa pemerolehan bahasa ini bersifat universal. Pada umur 2-3 tahun, seorang aaj yang normal sudah mengucapkan fonem-fonem dan kata yang terbatas sesuai dengan lingkungan sekolahnya dan sesuai dengan apa yang dipelajari dalam nyanyian meskipun pengucapannnya masih terpotong-potong dan pengucapannya masih terpeleset.

Pada umur 2-3 tahun nampaknya kata-kata yang diproduksi anak PAUD Nur Insani sudah mulai bertambah dan mulai dari kata benda dan kata kerja. Perkembangan perbendaharaan bahasanya sudah muklai dengan kata-kata benda yang abstrak. Sementara kata-kata benda dan kata kerja juga bertambah disebabkan oleh repetisi dari pemerolehan dari guru, teman dan lingkungan rumahnya.

Selain itu, anak PAUD Nur Insani sudah bisa merangkai kata-kata secara sederhana sesuai dengan kata yang ada dalam nyanyian Ayo Baris teman-teman tersebut. mereka merangkai dengan sederhana, mulai dari satu, dua sampai tiga kata, dan akhirnya membentuk kalimat. Kalimat sederhana yang dikemukakannya masih berkisar pada urutan sederhana dan belum teratur. Namun kalimat itu sudah dapat ditangkap kalimat-kalimat baik kalimat imperatif maupun kalimat permintaan yang diproduksi. Dari hasil pantauan, anak PUD Nur Insani kalimatkalimat tersebut sudah dapat diproduksi pada usia 2-3 tahun. Disamping kata-kata dan kalimat yang diperoleh seperti dikemukakan di atas, disini dapat pula disimpilkan bahwa seorang anak yang normal, akan mampu memperoleh bahasa pertama bila saraf dan jaringan otaknya tidak terganggu selama masa pertumbuhannya. Perkembangan kejiwaan dan juga gizi serta lingkungan, baik di rumah maupun di sekolahan memegang peranan penting dalam pertumbuhan motorik khususnya dalam pemerolehan produksi bahasa anak. 
DAFTAR PUSTAKA

Chomsky, N. (1975). Reflections of Language. New York: Pantheon Books.

Dardjowidjoyo, Soenjono. (2000). Echa: Kisah Pemerolehan Bahasa Anak Indonesia. (Jakarta: PT Gramedia Widiasarana Indonesia.

Indah, Rohmani Nur dan Abdurrahman. (2008). Psikolinguistik: Konsep dan Isu Umum. Malang: UIN Malang Press.

Ingram, D. and Stern (1989). Phonological disability in children. 2nd Ed. London: Cole and Whurr Ltd.

Ingram, David. (1989) First Language Acquisition Method, Description, and explanation. Cambridge University Press,

Kridalaksana, Harimurti. (2001). Kamus Linguistik. Jakarta: Gramedia Pustaka Utama.
Kuhl, P., Conboy, B. (2008). Phonetic learning as a pathway to language: New data and native language magnet theory expanded (NLM-e). Philosophical Transactions B, 363: 979-1000.

Lyons John, (1995). Pengantar Teori Linguistik. PT Gramedia Pusaka Utama Jakarta.

Masitoh, dkk. (2007). Strategi Pembelajaran TK. Yogyakarta: Bina Insantana.

Ramlan. (1997). Semantik: Pengantar Studi tentang Makna. Bandung: Sinar Baru.

Solehuddin, M. (1998). Konsep Dasar Pendidikan Pra Sekolah. Bandung: Depdikbud-FIP IKIP Bandung.

Sugiyono. (2013). Metode Penelitian

Pendidikan Pendekatan Kuantitatif,

Kualitatif, dan R\&D. Bandung: Alfabeta. 